\title{
Application of Acceptable Noise Level to Confirm Fitting Strategy for Bone-Anchored Hearing Aid
}

\author{
Sunghwa You ${ }^{1,2}$, Jihyun Lee ${ }^{2,3}$, Woojae Han ${ }^{1,2}$, Young Joon Seo ${ }^{3}$ \\ 'Division of Speech Pathology and Audiology, College of Natural Sciences, Hallym University, Chuncheon, Korea \\ ${ }^{2}$ Laboratory of Hearing and Technology, Research Institute of Audiology and Speech Pathology, Hallym University, Chuncheon, Korea \\ ${ }^{3}$ Department of Otorhinolaryngology, Yonsei University Wonju College of Medicine, Wonju, Korea
}

Received: November 26, 2019 Revised: December 17, 2019

Accepted: December 19, 2019

\section{Correspondence:}

Woojae Han, PhD

Division of Speech Pathology and Audiology, College of Natural Sciences, Hallym University,

1 Hallymdaehak-gil,

Chuncheon 24252, Korea

Tel: +82-33-248-2216

Fax: +82-33-256-3420

E-mail: woojaehan@hallym.ac.kr
Since there is no standardized fitting procedure for bone-anchored hearing aid (BAHA) patients, many clinics have failed to perform their successful fitting. The present case study tried to identify whether acceptable noise level (ANL) was clinically applied as one of fitting procedures for the BAHA users. Four hearing-impaired adults with BAHA ( 3 female and 1 male) who had a period of hearing deprivation for at least 8 years and the BAHA experience of more than 1 year participated. They conducted ANL in their unaided and aided BAHA conditions after being familiar with the ANL instruction. Also, the subjects responded to a self-report of Korean version of Profile of Hearing Aid Benefit (K-PHAB) to subjectively check amount of satisfaction with BAHA. Compared to the unaided condition, two out of four BAHA users showed a decreased ANL in the aided condition whereas the other users had a slightly increased ANL. Regardless, their levels were examined within the permissible range except for one subject. Their K-PHAB scores were similar to the ANL results in the aided condition. Although measured ANLs were slightly differed from the users, the current results suggest that ANL might be a tool to measure individual's inherent value when the BAHA fitting being appropriated while also supported by K-PHAB scores. In the following study, we need to confirm a typical pattern of many BAHA users with longitudinal measures of ANL.

Key Words: Bone-anchored hearing aids, Acceptable noise level, Korean version of Profile of Hearing Aid Benefit, Fitting, Satisfaction.

\section{INTRODUCTION}

골도 보청기[bone-anchored hearing aid (BAHA), bone conduction device]는 만성 중이염, 일측성 감각신경성 난청, 선천성 외이도 폐쇄증 등 다양한 이과적 원인으로 인해 보편화된 기도 보청기 착용에 제한을 갖는 환자들을 대상으로 Tjellström et al.(1980)에 의해 1980년 처음 제안되어 편측성 및 혼합성 난청 등 다양한 난청 범위로 확정되어 왔다. 이후 현재까지 전 세계적 으로 약 150,000 명 이상의 난청인들이 골도 보청기를 착용하는 것으로 추정되며 그 사용자는 해마다 꾸준히 늘어나고 있다 (Kara et al., 2019).

골도 보청기는 환자의 고막과 이소골의 보존 여부 및 상태와 관계없이 보장구 착용을 통하여 긍정적인 이득을 기대할 수 있

(c) This is an Open Access article distributed under the terms of the Creative Commons Attribution Non-Commercial License (https://creativecommons.org/licenses/by-nc/4.0) which permits unrestricted non-commercial use, distribution, and reproduction in any medium, provided the original work is properly cited.
고(Saroul et al., 2011), 일측성 난청을 갖는 환자에게도 골도 보청기의 착용 측에서 받아들여진 청각적 신호를 골전도를 통 해 대측 와우에 전달함으로써 양측의 청각적 자극을 모두 수용 할 수 있는 대안으로 환영받아 왔다(Hodgetts \& Scollie, 2017; Saroul et al., 2011). 그럼에도 일부 골도 보청기 착용자는 보장 구 사용에 낮은 만족감을 보이거나 착용 전 청력으로 예측되는 착용 후의 이득을 기대할 수 없다(Snik et al., 2005). 뿐만 아니 라 Hodgetts \& Scollie(2017)는 높은 착용 만족도를 보여준 골 도 보청기 대상자들 또한 어떠한 이득으로 인해 성공적인 적합 이 되었는지 정형화된 임상적 측정치가 없어 확인하기가 모호 하다고 지적하였다. 다시 말해 표준화된 실이 측정 절차(ANSI, 1997)가 있는 기도 보청기와는 대조적으로 골도 보청기의 적합 은 진동 자극이라는 기기적 특성으로 인해 실이 측정을 통한 미세 조정(fine-tuning)이 불가능하다(Hodgetts \& Scollie, 2017). 따라서 표준화 및 체계적인 절차의 부재로 인해 적합에 대한 접근 방식이 애매하고, 구체적인 적합 방법 및 절차들은 
임상에 따라 매우 상이하다. 또한 Dillon(2012)은 난청 환자가 임플란트 이식 수술을 진행하기 전에도 골도 보청기의 착용 전 후에 대한 이득 평가가 현재로써는 한계가 있고, 이식 전 밴드 형태로 착용하는 골도 보청기(e.g. BAHA softband)를 통한 이 득 예측 평가는 고주파수에서의 다소 큰 역치 차이로 인해 낮 은 평가-재평가 신뢰도를 초래하는 등 오히려 잘못되고 부적절 한 해석을 초래할 수 있다고 임상적 권장을 제한하였다.

한편 수용소음레벨(acceptable noise level, ANL)은 일반 청 취 환경 속에서 청취자가 수용할 수 있는 배경소음의 정도를 측정하는 방법으로써, 1991년 Nabelek et al.(1991)에 의해 처 음 시도되었다. 다양한 연구들을 통하여 수용소음레벨은 보장 구의 추가 기능 및 적합 상태에 따라 소음 속 어음인지(speech perception in noise)와는 달리, 보장구 착용 여부에 영향을 받 지 않는 개인의 내재적인 수치로 여겨졌다(Lytle, 1994). 정상 청력인을 대상으로 측정된 수용소음레벨이라도 연구자별로 다 소 차이가 있지만 국외에서는 평균적으로 6.4 15.9 dB의 범위 를 갖는 것으로 보고하였고(Freyaldenhoven et al., 2006; Nabelek et al., 1991; Nabelek et al., 2004; von Hapsburg \& Bahng, 2006), 한국어를 통해 측정된 정상 청력인의 평균 수용 소음레벨은 약 $7.8 \mathrm{~dB}$ 정도로 보고하였다(Shin \& Lee, 2010). 매우 드물지만 골도 보청기 착용자를 대상으로 수용소음레벨 을 측정하였던 Olsen et al.(2011)의 연구에서는 약 9.3 14.7 dB 범위에서 수용소음레벨이 나타났다.

Nabelek et al.(2006)은 배경소음에 대한 낮은 수용력으로 인해 기도 보청기 사용에 어려움을 겪는 대상자 선별을 목표로 흥미로운 실험을 진행하였고, 수용소음레벨이 낮은 연구 대상 자들, 즉 배경소음을 더 많이 수용하는 대상자들은 예상대로 기도 보청기에서 더 높은 사용률을 보고하였으며, 수용소음레 벨은 약 $85 \%$ 의 정확도를 갖고 난청인들의 보장구 사용에 대해 예측할 수 있는 요인이라 결론지었다. 이와 유사하게 수용소음 레벨과 보청기 만족에 대한 자가보고형 설문지인 Abbreviated Profile of Hearing Aid Benefit (APHAB) (Cox \& Alexander, 1995)의 연관성을 분석했던 Freyaldenhoven et al.(2008)의 연 구에서는 측정된 수용소음레벨과 $\mathrm{APHAB}$ 점수는 약 $91 \%$ 의 정확도로 기도 보청기의 사용률 및 만족도를 예측할 수 있음을 시사하였다. 이듬해에 Donaldson et al.(2009)의 연구에서도 인 공와우 이식 환자들을 대상으로 수용소음레벨과 $\mathrm{APHAB}$ 자 가보고 평가를 실시하여 착용자의 의사소통 능력의 예측 가능 성을 조사하였고, 수용소음레벨의 결과가 인공와우 착용자의 의사소통 능력과 높은 연관성을 갖음을 강조하였다.

이에 본 사례 연구에서는 4 명의 골도 보청기 착용자를 대상 으로 보장구 적합에 수용소음레벨 및 자가보고형 설문 평가를 접목함으로써, 골도 보청기 착용자의 적합 기준에 시도되지 않
았던 수용소음레벨의 임상적 적용 가능성을 확인하고자 하였 다. 이를 위해 다음과 같이 두 개의 가설을 설정하였다. 첫째, Nabelek et al.(1991)과 Lytle(1994)의 연구 결과에 기반하여 수 용소음레벨은 연구 대상자의 내재적인 수치로써 보장구 착용 여부에 따라 크게 변하지 않을 것이다. 즉, 골도 보청기 적합이 적절하게 시행되었다면 연구 대상자 각 개인의 수용소음레벨 은 보장구 착용 여부에 따라 큰 변동 없이 유지될 것이며, 이는 선행연구들에서 제안한 수용소음레벨의 범위에서 측정될 것이 다. 둘째, 골도 보청기 착용 후 수용소음레벨이 적정 범위에 있 는 연구 대상자는 주관적 자가보고 설문 결과에서도 보장구에 대한 만족감이 높게 나타날 것이다.

\section{CASE REPORT}

\section{연구 대상}

원주 세브란스 기독병원의 이비인후과에 방문하는 난청 환 자 4명(평균: 65.50세, 표준편차: 8.73)을 대상으로 사례 연구를 진행하였다. 연구 대상자는 모두 BAHA 착용 환자로, 편측성 난청 혹은 혼합성 난청으로 골도 보청기 착용에 적합한 청각학 적 특성을 보였다.

Figure 1에 제시한 각 연구 대상자의 순음청력역치를 살펴보 면 연구 대상자 1번[Subjects (S) 1] (Figure 1A)의 좌우측 기도 순음청력역치(4분법; $0.5 \sim 4 \mathrm{kHz}$ )는 각각 $111.25 \mathrm{~dB} \mathrm{HL}, 98.75$ $\mathrm{dB} \mathrm{HL}$ 이었으며 골도 순음청력역치는 각 $70.00 \mathrm{~dB} \mathrm{HL}, 43.75$ $\mathrm{dB}$ HL이었다. S2 (Figure 1B)의 좌우측 기도역치는 각각 76.25 $\mathrm{dB} \mathrm{HL}, 33.75 \mathrm{~dB}$ HL이었으며 골도 역치는 $66.00 \mathrm{~dB} \mathrm{HL}$, $16.25 \mathrm{~dB}$ HL이었다. S3 (Figure 1C)의 좌우측 기도역치는 $76.25 \mathrm{~dB} H L$ 과 $60.00 \mathrm{~dB} \mathrm{HL}$, 골도역치는 $35.00 \mathrm{~dB} \mathrm{HL}$ 과 $32.50 \mathrm{~dB}$ HL이었으며, 마지막 S4 (Figure 1D)의 좌우측 기도 역치는 $52.50 \mathrm{~dB} \mathrm{HL}$ 과 $70.00 \mathrm{~dB} \mathrm{HL}$, 골도역치는 $51.25 \mathrm{~dB}$ $\mathrm{HL}$ 과 $30.00 \mathrm{~dB}$ HL이었다.

연구 대상자들은 비록 청력역치 및 손실 원인에서는 약간의 차이를 나타냈지만, 공통적으로 최소 난청 기간은 8년 이상이 었고 수술 후 최소 1년 이상 지속적으로 골도 보청기를 착용해 오고 있다. 구체적으로 골도 보청기를 착용한 기간은 1 3년 정 도로 평균 1.75 년이었고 골도 보청기의 착용 방향이 좌측인 환 자는 2명(S1과 S3), 우측인 환자는 2명(S2와 S4)이었다. 또한 모 든 대상자는 골도 보청기 외에 대측 귀에 보청기를 착용하고 있었다. 각 대상자별로 구체적인 정보는 Table 1에 제시하였다.

연구 대상자들은 실험 참여 전 연구의 목적과 절차에 대하 여 설명을 듣고 연구에 대해 충분히 이해한 뒤 참여 동의서에 서명하였다. 

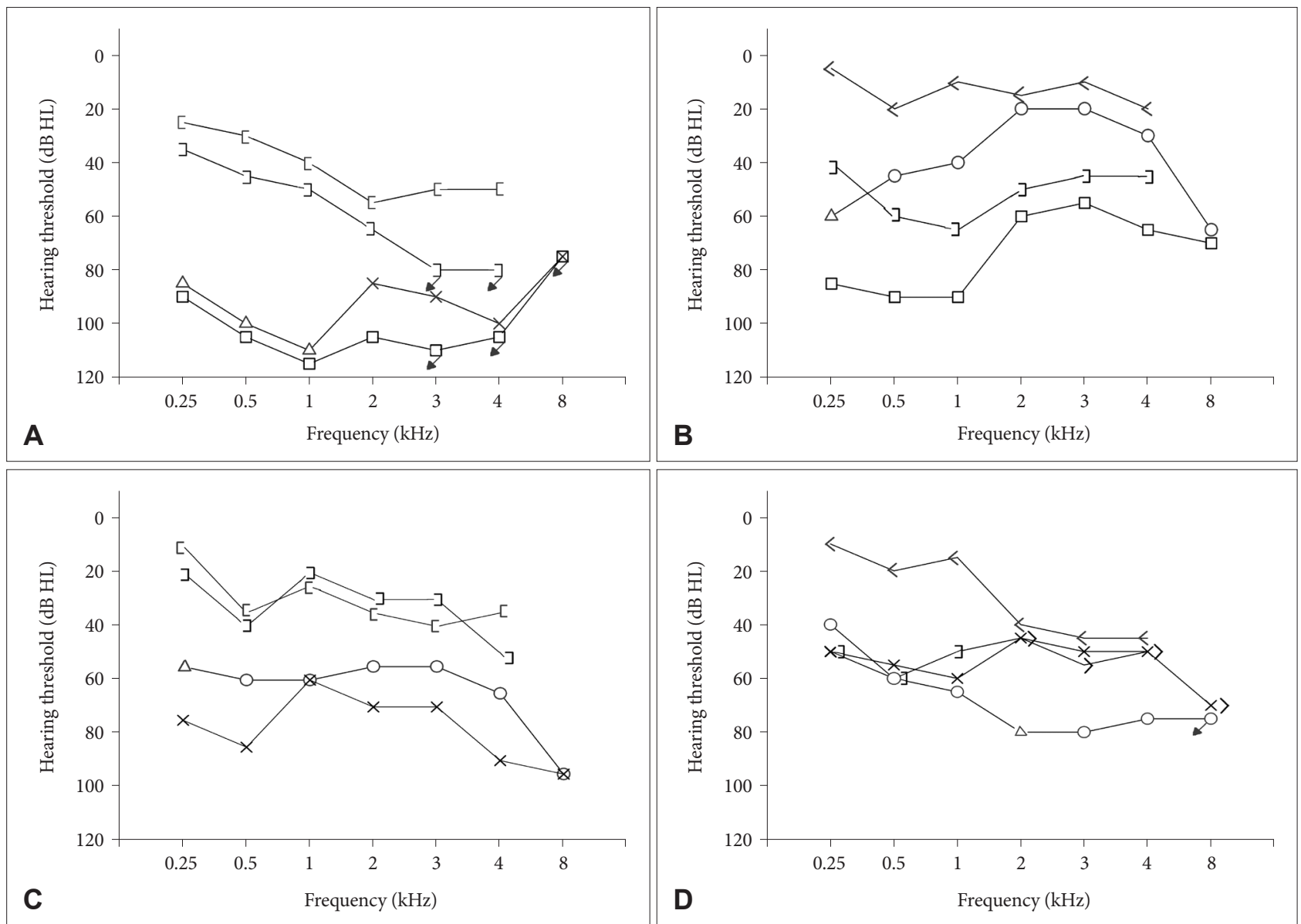

Figure 1. Results of the pure-tone audiogram for four individuals with bone-anchored hearing aid. A: The audiogram of S1 having bilaterally mixed hearing loss in all testing frequencies. B: The audiogram of S2 having bilaterally mixed hearing loss for only low frequencies. C: The audiogram of S3 having bilaterally mixed hearing loss in all testing frequencies. D: S4's audiogram having mixed hearing loss in right ear and sensorineural hearing loss in left ear. S: subject.

Table 1. Demographic and hearing information of four subjects with BAHA

\begin{tabular}{cccccccc}
\hline S & Sex & Age $(\mathrm{yr})$ & Period of HL & BAHA using period $(\mathrm{mo})$ & Etiology & BAHA/HA ear & Device of BAHA \\
\hline S1 & F & 59 & Congenital & 14 & OME, mixed HL & Lt/Rt & Baha $^{\circledR} 5$ power \\
S2 & F & 60 & Congenital & 19 & OME, SSNHL & Rt/Lt & ${\text { Baha }{ }^{\circledR} 5}^{5}$ \\
S3 & F & 65 & 8 years + & 33 & OME, dizziness & Lt $/ \mathrm{Rt}$ & Baha $^{\circledR}$ BP100 \\
S4 & M & 78 & 10 year + & 12 & OME, SNHL & Rt $/ \mathrm{Lt}$ & Baha $^{\circledR} 5$ \\
\hline
\end{tabular}

Baha $^{\circledR} 5$ power, Baha ${ }^{\circledR}$ 5, and Baha ${ }^{\circledR}$ BP100; Cochlear ${ }^{\mathrm{TM}}$. BAHA: bone-anchored hearing aid, S: subject, HA: hearing aid, F: female, M: male, OME: otitis media with effusion, HL: hearing loss, SSNHL: sudden sensorineural hearing loss, SNHL: sensorineural hearing loss, Lt: left ear, Rt: right ear

\section{연구 도구}

\section{수용소음레벨 측정 도구}

본 사례 연구에서는 Shin \& Lee(2010)에 의해 개발된 수용 소음레벨 도구를 사용하여 측정하였다. 선행연구에서 제작된 목표 어음은 수용소음레벨의 원리 및 활용 방안을 주창한 $\mathrm{Na}^{-}$ belek et al.(1991)의 방법을 기반으로, 한국어 원어민 6명의 목 표 어음(여성 3명, 남성 3명)과 8명의 다화자소음(여성 4명, 남 성 4명)을 사용하였다. 목표 어음은 6 명의 화자가 각각 5 분 동
안의 평이한 내용의 역사책을 읽은 후 각기 다른 파트를 무작 위로 추출하여 겹치는 내용이 없도록 제작되었다. 반면, 8 명의 다화자소음은 8 명의 화자가 동시에 신문 혹은 잡지를 읽은 것 을 믹싱하였다(Shin \& Lee, 2010).

수용소음레벨을 측정하기 위해 목표 어음 및 다화자소음을 방음실 검사 부스 내에서 GSI 61 (Grason-Stadler, Eden Prai$\mathrm{rie}, \mathrm{MN}, \mathrm{USA})$ 의 청력검사 기기와 이에 연결된 데스크톱(HP 280 G1 MT, HP, Palo Alto, CA, USA)을 사용하여 CD로 제 작된 음원으로 제시하였다. 청력검사기기의 Channel 1에서는 
목표 어음을, Channel 2에서는 다화자소음을 연구 대상자로부 터 $0^{\circ}$ 방위각(정면)의 $1 \mathrm{~m}$ 거리에 위치한 하나의 스피커(Control 1x, JBL, Northridge, CA, USA)를 통하여 동시에 제시하 였다.

\section{자가설문 보고 평가지}

본 사례 연구에서는 보청기 착용 전후 착용자의 심리음향적 인 이득과 다양한 청취 상황에서의 의사소통 능력의 변화를 평 가하기 위해 Cox \& Alexander(1995)에 의해 개발된 APHAB 설문평가지를 일부 변형하여 새로이 개발한 '한국어판 보청기 이득평가 설문지(Korean version of PHAB, K-PHAB)'를 적용 하였다(Kim et al., 2016). 사용한 K-PHAB 설문 도구는 '의사 소통의 용이함(ease of communication)', '배경소음(background noise)', '반향 정도(reverberation)', '음의 날카롭고 거슬 림(aversiveness of sounds), '방향성(localization)'의 5 가지 하 위 항목을 기반하여 총 20 문항으로 구성되었으며, 각 문항당 7점 척도를 사용하여 총 140 점 만점을 기준으로 적용하였다.

\section{연구 절차}

\section{수용소음레벨의 측정}

수용소음레벨을 측정하기 위해 대상자가 목표 어음을 듣는 데 가장 편안하게 느끼는 강도인 쾌적강도레벨(most comfortable level, MCL)을 측정한 후, 목표 어음을 듣는 동시에 다화 자잡음을 제시하여 대상자가 수용할 수 있는 소음 강도, 배경 소음레벨(background noise level, BNL)을 측정하였다. 그러 나 수용 가능한 소음 강도는 청력검사에서 사용되는 불쾌역치 (uncomfortable loudness level)의 측정과는 다른 개념이다. 즉, 불쾌역치는 자극음으로부터 불쾌감이나 압박감, 통증 등을 느 끼는 최대한의 강도를 의미하지만, 수용소음레벨에서 측정하는 배경소음레벨은 제시되는 배경소음이 목표 어음을 인지하는 데 방해가 되지 않는 동시에 허용할 수 있는 최대한의 소음 강 도를 의미한다(Olsen \& Brännström, 2014). 따라서 대상자의 검사에 대한 이해를 위해 평가 전 수용소음레벨의 검사 목적 및 설명을 글로 명확히 작성하여(Shin \& Lee, 2010) 연구 대상 자가 스스로 이해하도록 충분한 시간을 제공한 후 검사에 대해 충분한 설명이 진행되었다고 판단되었을 때 측정을 실시하였다.

앞서 언급된 쾌적강도레벨 및 배경소음레벨 측정은 모두 $2 \mathrm{~dB}$ 간격으로 측정하였고, 측정된 레벨들은 그 차이를 통해 수용소 음레벨(ANL $=\mathrm{MCL}-\mathrm{BNL})$ 을 산출하였다. 수용소음레벨의 낮은 검사-재검사 신뢰도를 보고했던 Olsen et al.(2012)의 선행 연구에 근거하여, 본 연구에서는 수용소음레벨 절차를 3 회 반 복하여 측정하였으며, 각 쾌적강도레벨 및 배경소음레벨의 평
균값을 기반으로 각 연구 대상자의 수용소음레벨을 최종적으 로 결정하였다.

\section{자가설문 보고 측정}

본 사례 연구에서는 K-PHAB 설문지(Kim et al., 2016)를 사용하여 대상자들의 골도 보청기 착용에 대한 주관적인 만족 도를 측정하여 수용소음레벨과의 연관성을 검증하고자 하였 다. 따라서 수용소음레벨의 측정이 완료된 후, 모든 대상자들 에게 K-PHAB 설문지를 시행하였다. 다만 골도 보청기 착용 시의 상황을 좀 더 확실하게 설문하기 위해서, 골도 보청기 미 착용 시 상황 또한 해당 문항에 응답하도록 요구하였다. 모든 대상자는 골도 보청기와 함께 대측 귀에 기도 보청기를 착용하 였기 때문에, 이에 의한 효과를 막기 위해 설문 시 골도 보청기 만을 착용한 상태에서 응답하도록 재차 강조하였다.

\section{연구 결과}

수용소음레벨은 개인의 내재적인 수치라는 전제(Lytle, 1994; Nabelek et al., 1991)하에, 본 연구에서는 골도 보청기의 피팅 이 적절하게 진행되었다면 수용소음레벨 수치에 큰 변화가 없 을 것으로 가정하였고, 골도 보청기 착용 시 수용소음레벨이 허용 가능 범위에 속하는 연구 대상자는 보장구 착용에 대하 여 주관적으로 보고되는 만족도가 높을 것으로 가설하였다.

\section{골도 보청기 착용 후 이득 평가}

골도 보청기 착용 역치는 음장(sound field)하에서 골도 보청 기만을 착용한 상태로 진행되었고, 보장구 착용으로 인한 기능 이득(functional gain)을 예측하기 위해 4분법을 기준으로 음 장하 골도 보청기 착용 역치와 좋은 쪽 귀의 기도역치 차이로 분석하였다. 또한 음장검사 시 좋은 쪽 귀의 영향을 최소화하기 위해 좋은 쪽 귀는 귀마개(Ear Plug 1100, Maplewood, MN, USA) 착용 후 검사하였다. Table 2 는 본 사례 연구에 참여한 4 명의 골도 보청기 착용 환자의 수술 후 최소 6 개월이 지났고 적 합에 큰 변화가 없는 상황에서 방음실의 스피커를 활용하여 실 시한 골도 보청기 착용 역치 및 기능이득의 결과이다.

각 대상자별로 살펴보면 $\mathrm{S} 1$ 의 보장구 착용 역치는 4 분법 기 준 $48.75 \mathrm{~dB}$, 좋은 쪽 귀 기도역치는 $98.75 \mathrm{~dB}$ 로 $50 \mathrm{~dB}$ 의 기능 이득이 있었다. $\mathrm{S} 2$ 는 $32.50 \mathrm{~dB}$ 의 보장구 역치 및 $33.75 \mathrm{~dB}$ 의 기 도역치로 $1.25 \mathrm{~dB}$ 의 기능이득이 있었으며, $\mathrm{S} 3$ 은 보장구 착용 역치는 $58.75 \mathrm{~dB}$, 기도역치는 $60.00 \mathrm{~dB}$ 로 $1.25 \mathrm{~dB}$ 의 기능이득 이 있었다. 마지막 $\mathrm{S} 4$ 는 보장구 착용역치는 $48.75 \mathrm{~dB}$, 기도역치 는 $52.50 \mathrm{~dB}$ 로 $6.75 \mathrm{~dB}$ 의 기능이득이 있었다. 총 네 명의 골도 보청기 대상자의 기능이득의 관점에서, 보장구 착용 역치와 좋 은 쪽 귀의 기도역치를 비교했을 때 1 번 대상자를 제외하고 비 
Table 2. Aided thresholds of the subjects in terms of frequency and their results of speech perception when wearing the bone-anchored hearing aids

\begin{tabular}{|c|c|c|c|c|c|c|c|c|c|}
\hline \multirow{2}{*}{ S } & \multicolumn{6}{|c|}{ Aided thresholds (dB HL) } & \multirow{2}{*}{ Functional gain } & \multirow{2}{*}{ SRT (dB HL) } & \multirow{2}{*}{ WRS (\%) } \\
\hline & $0.25 \mathrm{kHz}$ & $0.5 \mathrm{kHz}$ & $1 \mathrm{kHz}$ & $2 \mathrm{kHz}$ & $3 \mathrm{kHz}$ & $4 \mathrm{kHz}$ & & & \\
\hline S1 & 65 & 45 & 40 & 40 & 60 & 70 & 50 & 56 & 48 \\
\hline S2 & 35 & 35 & 35 & 30 & 30 & 30 & 1.25 & 34 & 96 \\
\hline S3 & 75 & 70 & 50 & 50 & 75 & 65 & 1.25 & 60 & 40 \\
\hline S4 & 50 & 55 & 45 & 45 & 60 & 50 & 6.75 & 64 & 62 \\
\hline
\end{tabular}

S: subject, SRT: speech recognition threshold, WRS: word recognition score
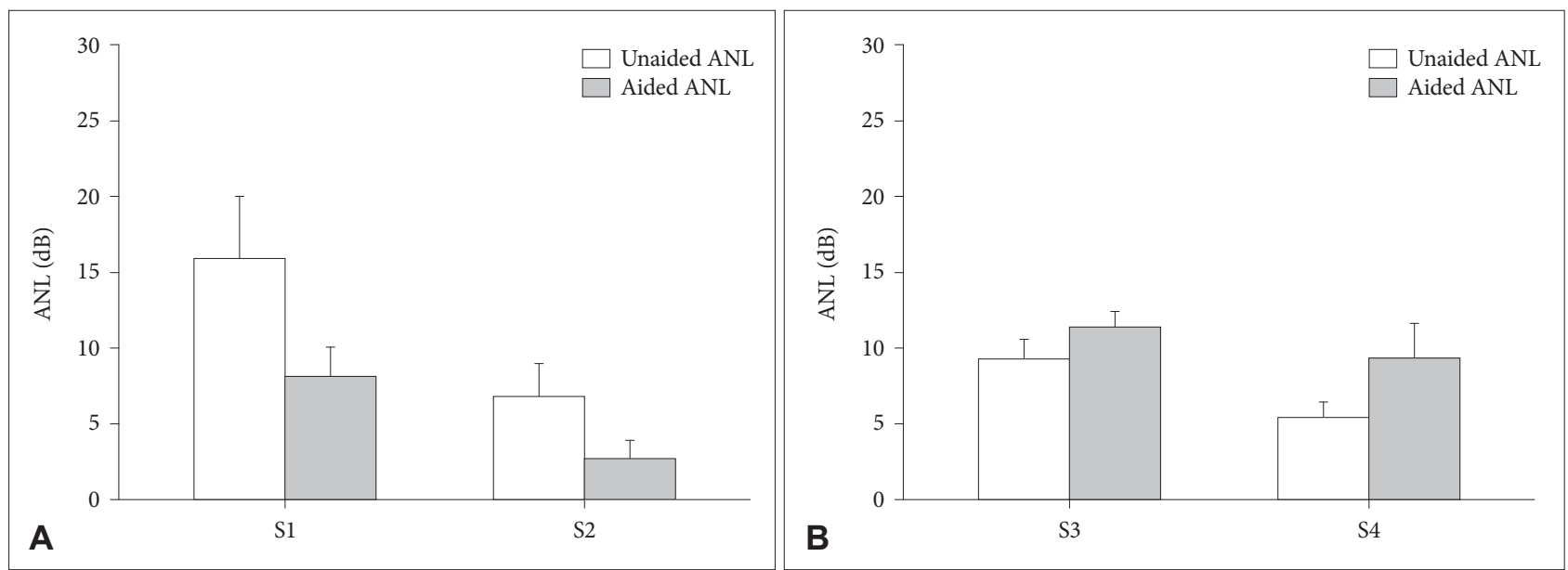

Figure 2. Comparison of unaided and aided ANLs for individuals. S1 and S2 were reduced ANL with aided BAHA (A), whereas S3 and S4 had a slightly higher ANL with aided BAHA (B). S: subject, ANL: acceptable noise level, BAHA: bone-anchored hearing aid.

교된 두 역치(보장구 착용 역치 및 좋은 쪽 귀 기도역치)에 큰 차이가 없었다. 즉, 보장구 착용 역치와 좋은 쪽 귀의 역치가 유 사한 경향을 나타내었다. 그러나 1 번 대상자의 경우 $50 \mathrm{~dB}$ 의 차 이를 보이는데, 이러한 이유로는 다른 대상자에 비해 $\mathrm{S} 1$ 은 상대 적으로 매우 높은 기도역치(Rt: $98.75 \mathrm{~dB} \mathrm{HL}, \mathrm{Lt}: 111.25 \mathrm{~dB}$ $\mathrm{HL})$ 에 기인한 것으로 추정되며, 좋은 쪽 귀의 기도역치보다는 골도역치(43.75 dB HL)와 보장구 착용 역치가 유사함을 확인 할 수 있다.

\section{수용소음레벨의 측정 결과}

골도 보청기의 적합이 적절히 되었다면 개인의 내재적 수치 인 수용소음레벨은 변동이 없을 것이라는 가정과는 상이하게, 보장구 착용 여부에 따라 수용소음레벨은 약간의 수치적 차이 를 관찰하였다. 예를 들어 미착용 상황에서 $\mathrm{S} 1 \sim \mathrm{S} 4$ 대상자의 쾌 적강도레벨의 평균은 각각 $80,51.3,73.3,74 \mathrm{~dB}$ 이었으며 배경 소음레벨의 평균은 각각 $64,44.7,68,64.7 \mathrm{~dB}$ 이었다. 수용소음 레벨이 감소한 Figure 2A의 S1과 S2 대상자는 미착용 상황에 서 각각 $16.00,6.67 \mathrm{~dB}$ 이었으나 착용 상황에서 수용소음레벨 이 각각 $8.00,2.67 \mathrm{~dB}$ 로 나타나 골도 보청기를 착용한 후 평균 $6 \mathrm{~dB}$ 정도 수용소음레벨이 감소하였다. 이와 반대로 Figure $2 \mathrm{~B}$ 의 수용소음레벨이 상승한 $\mathrm{S} 3$ 과 $\mathrm{S} 4$ 의 경우에는 미착용 상
황에서 수용소음레벨은 각각 $9.33 \mathrm{~dB}$ 과 $5.33 \mathrm{~dB}$ 이었으나 착용 시 수용소음레벨은 각각 $11.33 \mathrm{~dB}$ 과 $9.33 \mathrm{~dB}$ 로 나타나 오히려 골 도 보청기를 착용하고 약 $3 \mathrm{~dB}$ 정도 상승하였다. 이러한 결과 해 석 시 낮은 반복성을 갖는 수용소음레벨의 특성상 $2 \sim 5 \mathrm{~dB}$ 의 수 용소음레벨 차이는 큰 시사점이 없다고 판단하였고(Freyaldenhoven et al., 2006), Gordon-Hickey et al.(2012)의 연구에서도 이러한 차이는 임상적으로 크게 중요하지 않음을 지지하였다. 그러나 Ho et al.(2013)의 연구에서는 수용소음레벨의 $3 \mathrm{~dB}$ 차 이는 임상적으로 유의미한 차이임을 주장하는 등 연구자들 간 에도 수용소음레벨의 차이에 대해 이질성을 보고하였다. 따라 서 본 연구에서 수용소음레벨이 $3 \mathrm{~dB}$ 감소했던 S3과 S4의 수 용소음레벨의 변동을 추후 임상적 해석 단계에서 주의를 기울 여야 할 것이다.

그럼에도 착용 전후의 수용소음레벨에서의 약간의 변동에 대하여 좀 더 논의해 본다면, 본 사례 연구에서는 착용 시의 수 용소음레벨 측정 과정에서 연구 대상자들의 골도 보청기의 소 음감쇄기능(noise reduction)이 켜져 있는 평소 상태를 유지하 도록 요구하였다. 물론 보장구별로 상이함이 존재하지만, $\mathrm{Ol}-$ sen et al.(2011)의 선행연구에서 실시된 소음감쇄기능을 켠 상 태의 수용소음레벨의 평균은 9.3 14.7 dB (범위: -5.3 25.3 dB) 이고, 소음감쇄기능을 작동하지 않은 상황에서의 수용소음레 
벨은 10.7 12.7 dB (범위: -0.7 29.3 dB)로 보고하였다. 이는 기 도 보청기에서도 소음감쇄기능은 대상자의 수용소음레벨을 약 3 4 dB 정도 감소시키는 것으로 Freyaldenhoven et al.(2005) 과 Mueller et al.(2006)의 연구 결과로도 알려져 있기에 설득력 이 있다. 종합해 보면 본 연구 대상자들의 골도 보청기 착용 시 수용소음레벨은 2.7 11.3 dB 정도로 선행연구에서 보고된 결 과보다는 조금 낮지만, 소음감쇄기능으로 인한 감소 정도를 고 려한다면 유사한 범위에서 나타난 것으로 확인할 수 있다. 결론 적으로 본 사례에서 나타난 골도 보청기의 미착용과 착용 상황 의 비교 시 수용소음레벨의 $3 \mathrm{~dB}$ 상승 혹은 $6 \mathrm{~dB}$ 감소 등의 변 동은 소음감쇄기능에서 기인한 것으로 추정할 수 있겠다.

\section{$\mathrm{K}-\mathrm{PHAB}$ 자가보고 설문 결과}

허용 범위 내에서 수용소음레벨이 측정된 착용자는 골도 보 청기 착용에 대하여 어느 정도 높은 만족도를 보고할 것으로 가 정하였다. 연구자별로 다소 차이는 있었지만, 정상 청력의 성인 들을 대상으로 수용소음레벨을 측정했던 연구들은 평균 6.4 $15.9 \mathrm{~dB}$ 의 범위 내에서 수용소음레벨을 보고하였고(Freyaldenhoven et al., 2006; Nabelek et al., 1991; Nabelek et al., 2004; von Hapsburg \& Bahng, 2006), 특히 한국어 자극음을 사용하여 측정된 수용소음레벨은 평균 $7.8 \mathrm{~dB}$ (범위: 0 16)로 보고된다(Shin \& Lee, 2010). 이러한 기준에 근거하여 S2의 수 용소음레벨 결과는 선행연구 결과에 비해 상당히 낮은 수치를 나타냈기에, 수용소음레벨과 K-PHAB 점수에 대한 상관성 분 석에서 제외하였다.

Figure 3은 연구 대상자 S1, S3, S4의 착용 중인 골도 보청기 에 대한 $\mathrm{K}-\mathrm{PHAB}$ 의 주관적인 만족도 평가 결과를 각 대상자 별로 총 140점 만점을 기준으로 측정된 수용소음레벨 수치와 비교하였다. 구체적으로 살펴보면 세 명의 연구 대상자의 골도

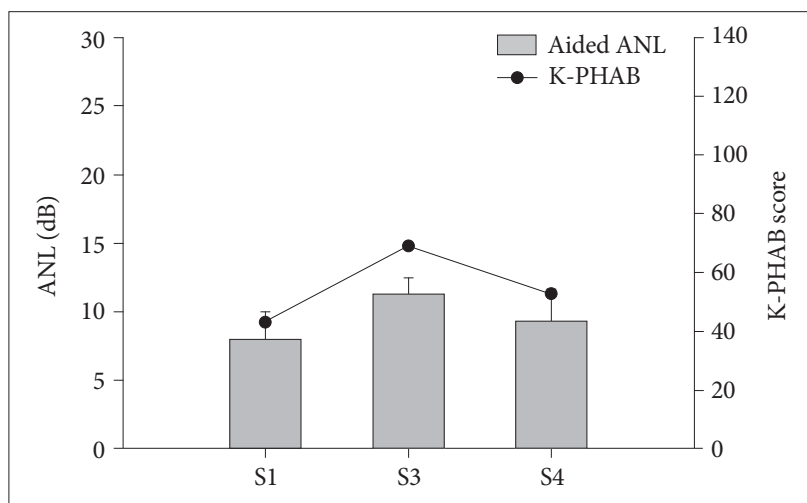

Figure 3. Comparison of ANLs (left Y-axis) and K-PHAB scores (right $Y$-axis) for three bone-anchored hearing aid patients (S1, S3, S4). While bars indicating mean of ANLs and its variance in the aided condition, the line graph provides K-PHAB scores for three patients. ANL: acceptable noise level, K-PHAB: Korean version of Profile of Hearing Aid Benefit.
보청기 착용 시 수용소음레벨과 K-PHAB 결과와 매우 유사한 결과치 및 패턴을 보였다. 즉, 가장 높았던 수용소음레벨을 갖 는 S3의 경우 $\mathrm{K}-\mathrm{PHAB}$ 의 만족도는 3명 중 가장 높게 나타났 다. 또한 $\mathrm{S} 1$ 과 $\mathrm{S} 4$ 의 연구 대상자의 경우 $\mathrm{K}-\mathrm{PHAB}$ 의 하위 영역 중 방향성 측면에서의 이득을 가장 높게 평가하였고, S3의 경 우 날카롭고 거친 소리에서의 이득을 가장 높게 평가하였다.

\section{DISCUSSIONS}

본 사례 연구에서는 골도 보청기 착용자들을 대상으로 수용 소음레벨 및 $\mathrm{K}-\mathrm{PHAB}$ 를 통한 자가설문 평가를 진행함으로써, 골전도 보청기 착용자의 적합 기준이 전무한 현재 수용소음레 벨을 통하여 임상적 적용 가능성을 확인하고자 하였다.

첫 번째 가설인 '수용소음레벨은 각 개인의 내재적인 수치로 써 골도 보청기의 적합이 안정적으로 잘 이루어졌다면 수용소 음레벨은 변하지 않을 것이다는 부분적으로 지지되었다. 즉, 본 연구에 참여한 최소 1 년 이상 골도 보청기를 착용한 경험을 갖 은 환자들은 미착용과 착용 상황에 따라 수용소음레벨이 소폭 저하 혹은 소폭 상승하는 경향을 보였다. 비록 4명의 적은 대상 자 수로 인해 수용소음레벨의 임상적 적용 가능성을 일반화할 수 없지만, Olsen et al.(2011)의 연구에서 제시되었던 골도 보청 기 착용자의 수용소음레벨 범위와 유사함을 보여 적용 가능성 을 증명하였다. 두 번째 가설인 골도 보청기의 적합이 적절하게 진행되었다는 가정하에, 착용 시 수용소음레벨이 허용 범위에 서 측정되는 착용자들은 골도 보청기 착용에 대하여 주관적으 로 보고되는 만족도가 높을 것으로 기대하였다. 이에 해당하는 3 명의 골도 보청기 착용자에게 적용한 K-PHAB 자가보고 결 과는 착용 시 수용소음레벨과 매우 유사함을 확인하였다.

향후 수명의 연장과 삶의 질의 향상과 관련하여 기존의 보청 기의 착용이 불가능하거나 인공와우 수술을 시행하기에는 좋 은 청력역치를 지닌 난청 환자들에게 골도 보청기 수술의 좀 더 안정적이고 편안한 듣기 상황을 제공할 것으로 기대한다. 그 러나 골도 보청기의 적합에 대한 과학적인 음향심리적 증명이 없다면 증가하고 있는 골도 보청기의 수술 대상자들을 안정적 으로 관리하기 어려울 것이다. 따라서 본 사례 연구 결과를 바 탕으로 좀 더 연구 방법을 보완하여 많은 종적 및 횡적 실험들 을 시도하여 골도 보청기의 이득을 근거 기반된 임상적 적용을 제공할 필요가 있겠다.

중심 단어 : 골도 보청기·수용소음레벨·한국어판 보청기이득 평가 설문지·적합·만족.

\section{Ethical Statement}

This study was approved by the Institutional Review Board of Wonju 
Severance Christian Hospital (CR316089).

\section{Acknowledgments}

The authors thank our participants with active and voluntary cooperation.

\section{Declaration of Conflicting Interests \\ There are no conflict of interests.}

\section{Funding}

This work was supported by the Ministry of Education of the Republic of Korea and the National Research Foundation of Korea (NRF-2018 S1A3A2074932).

\section{Author Contributions}

All authors designed the experiment together; S.Y. and J.L. performed experiments in the clinic; S.Y. wrote the draft of the manuscript, Y.S. provided critical revision, and W.H. revised the manuscript as the final version. Also, the authors discussed the results together and implications and commented on the manuscript at each stage.

\section{ORCID iDs}

Sungwha You

Woojae Han

https://orcid.org/0000-0003-2458-4509

https://orcid.org/0000-0003-1623-9676

\section{REFERENCES}

American National Standards Institute (ANSI). (1997). Method for the Calculation of the Speech Intelligibility Index (ANSI 53.79-1997). New York, NY: ANSI.

Cox, R. M. \& Alexander, G. C. (1995). The abbreviated profile of hearing aid benefit. Ear and Hearing, 16(2), 176-186.

Dillon, H. (2012). Hearing Aids. (2nd ed). New York, NY: Thieme.

Donaldson, G. S., Chisolm, T. H., Blasco, G. P., Shinnick, L. J., Ketter, K. J., \& Krause, J. C. (2009). BKB-SIN and ANL predict perceived communication ability in cochlear implant users. Ear and Hearing, 30(4), 401410

Freyaldenhoven, M. C., Fisher Smiley, D., Muenchen, R. A., \& Konrad, T. N. (2006). Acceptable noise level: Reliability measures and comparison to preference for background sounds. Journal of the American Academy of Audiology, 17(9), 640-648

Freyaldenhoven, M. C., Nabelek, A. K., Burchfield, S. B., \& Thelin, J. W. (2005). Acceptable noise level as a measure of directional hearing aid benefit. Journal of the American Academy of Audiology, 16(4), 228-236.

Freyaldenhoven, M. C., Nabelek, A. K., \& Tampas, J. W. (2008). Relationship between acceptable noise level and the abbreviated profile of hearing aid benefit. Journal of Speech, Language, and Hearing Research, 51(1), 136-146.

Gordon-Hickey, S., Moore, R. E., \& Estis, J. M. (2012). The impact of listening condition on background noise acceptance for young adults with normal hearing. Journal of Speech, Language, and Hearing Research, 55(5), 1356-1372.

Ho, H. C., Wu, Y. H., Hsiao, S. H., Stangl, E., Lentz, E. J., \& Bentler, R. A. (2013). The equivalence of acceptable noise level (ANL) with English, Mandarin, and non-semantic speech: A study across the U.S. and Tai- wan. International Journal of Audiology, 52(2), 83-91.

Hodgetts, W. E. \& Scollie, S. D. (2017). DSL prescriptive targets for bone conduction devices: Adaptation and comparison to clinical fittings. International Journal of Audiology, 56(7), 521-530.

Kara, A., Guven, M., Sinan Yilmaz, M., Demir, D., Adigul, C.., Durgut, M., et al. (2019). Comparison of two different bone anchored hearing instruments: Baha-5 vs Ponto-plus. Acta Oto-laryngologica, 139(6), 517521.

Kim, T., Sim, S., \& Lee, K. (2016). Development of Korean version of profile of hearing aid benefit. Audiology and Speech Research, 12(4), 209220.

Lytle, S. R. (1994). A comparison of amplification efficacy and toleration of background noise in hearing impaired elderly persons. (Unpublished master's thesis). University of Tennessee, Knoxville, TN.

Mueller, H. G., Weber, J., \& Hornsby, B. W. (2006). The effects of digital noise reduction on the acceptance of background noise. Trends in Amplification, 10(2), 83-93.

Nabelek, A. K., Freyaldenhoven, M. C., Tampas, J. W., Burchfiel, S. B., \& Muenchen, R. A. (2006). Acceptable noise level as a predictor of hearing aid use. Journal of the American Academy of Audiology, 17(9), 626639.

Nabelek, A. K., Tampas, J. W., \& Burchfield, S. B. (2004). Comparison of speech perception in background noise with acceptance of background noise in aided and unaided conditions. Journal of Speech, Language, and Hearing Research, 47(5), 1001-1011.

Nabelek, A. K., Tucker, F. M., \& Letowski, T. R. (1991). Toleration of background noises: Relationship with patterns of hearing aid use by elderly persons. Journal of Speech, Language, and Hearing Research, 34(3), 679-685.

Olsen, S. Ø. \& Brännström, K. J. (2014). Does the acceptable noise level (ANL) predict hearing-aid use? International Journal of Audiology, 53(1), 2-20.

Olsen, S. Ø., Glad, H., \& Nielsen, L. H. (2011). Comparison of two bone anchored hearing instruments: BP100 and Ponto Pro. International Journal of Audiology, 50(12), 920-928.

Olsen, S. Ø., Nielsen, L. H., Lantz, J., \& Brännström, K. J. (2012). Acceptable noise level: Repeatability with Danish and non-semantic speech materials for adults with normal hearing. International Journal of $\mathrm{Au}$ diology, 51(7), 557-563.

Saroul, N., Gilain, L., Montalban, A., Giraudet, F., Avan, P., \& Mom, T. (2011). Patient satisfaction and functional results with the bone-anchored hearing aid (BAHA). European Annals of Otorhinolaryngology, Head and Neck Diseases, 128(3), 107-113.

Shin, J. B. \& Lee, J. H. (2010). Effects of the target talker gender and the number of competing talkers on acceptable noise level (ANL) of Korean normal-hearing adults. Audiology, 6(2), 146-152.

Snik, A. F. M., Mylanus, E. A., Proops, D. W., Wolfaardt, J. F., Hodgetts, W. E., Somers, T., et al. (2005). Consensus statements on the BAHA system: Where do we stand at present? The Annals of Otology, Rhinology and Laryngology. Supplement, 114(12_Suppl 195), 2-12.

Tjellström, A., Håkansson, B., Lindström, J., Brånemark, P. I., Hallén, O., Rosenhall, U., et al. (1980). Analysis of the mechanical impedance of bone-anchored hearing aids. Acta Oto-Laryngologica, 89(1-2), 85-92.

von Hapsburg, D. \& Bahng, J. (2006). Acceptance of background noise levels in bilingual (Korean-English) listeners. Journal of the American Academy of Audiology, 17(9), 649-658. 